\title{
The Implementation of Flipped Classroom Model in Teaching English to Junior High School Students
}

\section{N.P. Sara Sintia Dewi ${ }^{1 *}$, N.N. Padmadewi², M. Hery Santosa ${ }^{3}$}

1,2,3 English Language Education, Post Graduate Program, Universitas Pendidikan Ganesha, Singaraja, Indonesia

\begin{tabular}{l} 
A R T I C L E I N F O \\
\hline Article history: \\
Received 18 December \\
2020 \\
Received in revised \\
Form 06 January 2021 \\
Accepted 20 January 2021 \\
Available online 01 \\
February 2021
\end{tabular}

Keywords:

Flipped Classroom, Implementation, Opinion, Teaching English

\begin{abstract}
A B S T R A C T
This research investigated (1) the implementation of Flipped Classroom for teaching English; (2) the students' achievement; (3) the students' opinion; and (4) the differences between the high and low achieving students' opinion toward Flipped Classroom. There were 41 seventh grade students and one English teacher of the seventh grade investigated. In this research, interview, questionnaires and lesson plan analysis were analyzed using interactive model; meanwhile the post-test and high and low achieving students' opinion given were statistically analyzed using SPSS 16 . It was resulting that in implementing Flipped Classroom the teacher did several preparations and teaching procedures which differentiated the classroom activity and home activity; the students' achievement was seen to be good; the students also perceived the learning positively; the differences among high and low achieving students' opinion were not significantly seen. This research helps the teacher who wants to implement flipped classroom as a consideration in teaching.
\end{abstract}

\section{Introduction}

The term of ' $21^{\text {st }}$ century' has brought changes to human development in every aspect, science, education, economic, technology and communication system. The interest of inserting of technology and the internet into the teaching and learning processes has significantly increased (Filiz \& Benzet, 2018; Uzunboylu \& Karagozlu, 2015). A digital learning which engage the $21^{\text {st }}$ century learning that supports students' learning intention should be applied. In order to make the classroom student-centered not teacher-centered, inserting Information and Communication Technologies (ICTs) is required (Trucano, 2005). The insertion of ICTs provides students the availability to study anywhere and everywhere (Evseeva \& Solozhenko, 2015). It provides students the opportunities to involve actively in the classroom. However, the classroom situation does not exactly align to the $21^{\text {st }}$ learning expectation. Most of the class time is used by the teacher to explain the learning material (Afrilyasanti, Cahyono, \& Astuti, 2016) which is considered as teacher-centered learning (Bjork, 2005). This situation cannot support students to think critically since they are totally helped by the teacher.

Students should not be filled with abundant of knowledge for the rest of their learning, but they should find new knowledge and experience, analyze and conclude it as they need (Evseeva \& Solozhenko, 2015). When students are lectured by the teacher, listening and memorizing are taken place. Students could not develop their skills in terms of creativity. Learning by doing instead of listening passively involved students into the learning process (Saglam \& Arslan, 2018). However, in order to face the $21^{\text {st }}$ century requirements, student-centered learning is highly enhanced (Saglam \& Arslan, 2018) (Alsowat, 2016; Lou \& Li, 2018). Thus, in order to fulfill the students' learning requirements, teacher as an educator should be familiar about the learning features that promotes students' effective learning (Santosa, 2017).

In this era, technology has played as the key role in human life and education. Everything which is done by human are affected by technology. Based on this case, flipped classroom is a learning model which utilize technology in it, thus, it is compatible to be applied in learning English. Flipped classroom model reverses the activities which are usually done at school is done at home (Herreid \& Schiller, 2013). It reverses the traditional classroom activity where teacher delivers the materials in the classroom. The activities which are usually done at school like lecturing and taking notes are conducted at home and students are provided video and sources by the teacher with the help of technology. Flipped classroom 
offers students opportunity in personalizing their learning as students have different capabilities in acquiring knowledge, student-centered learning, and constructivism (Basal, 2015).

2013 curriculum was designed to support Indonesian to be able to live as productive, creative, innovative and effective in world civilization (Amat et al., 2014). The learning process which is held at school should be inspiring, motivating, challenging, active, interactive and able to foster students' ability. The emergence of the 2013 curriculum is due to the globalization era where the information and communication technology have been widely used in everyday life; moreover, it is also seen that Indonesian former curriculum is only focusing on the knowledge aspects without considering students' characters (Marlina, 2013). By the implementation of 2013 curriculum in Indonesia, it is assumed that there is wider development in term of knowledge and technology. Productive, creative, innovative and effective human resources by strengthen the attitude, knowledge, and skills are expected in 2013 curriculum (Retnawati, et al., 2016). The 2013 curriculum emphasizes on active and independent learning (Shafa, 2014). Thus, the proposed of the 2013 curriculum fits the curriculum requirement.

Aligned with the 2013 curriculum, the Partnership for the $21^{\text {st }}$ Century Learning (P21) creates the framework for the $21^{\text {st }}$ century learning. It was created to prepare the students to face the $21^{\text {st }}$ century era which requires them to be creative and innovative in competing in their work and life (Borowski, 2019). In order to compete in the $21^{\text {st }}$ century era, there are eleven competencies should be managed based on the Partnership for $21^{\text {st }}$ century skill. Those competencies are classified into three qualifications namely, learning and innovation skills; information, media and technology skills; and life and career skills (Chu et al., 2016 \& Pearson, 2013). According to P21 there were 9 subjects including English, reading or language arts; world languages; arts; mathematics; economics, science, geography; history; government and civics should be mastered as the content knowledge of the $21^{\text {st }}$ century.

Learning and innovation skills cannot be separated from students' learning since these skills are recognized to be able to promote students' life and work. Learning and innovation skills is divided into four parts, creativity and innovation; critical thinking; communication; and collaboration (P21). Technology promotes and facilitates students' learning in the $21^{\text {st }}$ century learning; mobile devices can be used as the learning media which help students to access information everywhere and every time (Trilling \& Fadel, 2008; West \& Vosloo, 2013). There are three things in this skill includes information literacy; media literacy; and ICT (Information, Communications, and Technology) literacy (P21). In the $21^{\text {st }}$ century era, students are required to face the challenges in their future working place or in their daily life. Developing certain skills socially and emotionally are crucial. In order to prepare workers which are $21^{\text {st }}$ century oriented, educational institutions are expected to emphasizes on life and career skills (Abdullah et al., 2020). Those skills are Flexibility and Adaptability; Initiative and Self-Direction; Social and CrossCultural Skills; Productivity and Accountability; and Leadership and Responsibility (P21).

The existence of the 2013 curriculum and the $21^{\text {st }}$ century learning related to the $21^{\text {st }}$ century learning. Flipped classroom is an action of inverting the usual class learning activity with home learning activity (Bergmann \& Sams, 2012; Herreid \& Schiller, 2013). There are three main activity done in implementing Flipped Classroom, namely Pre-class activity; In-class activity; and Post-class activity. Preclass activity consists of modelling and pre-assessment; In-class activity consists of clarifying concepts and solving problem; while Post-class activity consists of assessment, application and transfer (Estes, et al., 2014). In flipped classroom, teachers are expected to talk to each student every day or in every meeting (Bergmann \& Sams, 2012). Teacher can reach every student who ask question and helped them based on their problem and capability. Teacher have more time to engage in one-on-one conversation with students and challenge them since content delivering has been done at home (Hall \& DuFrene, 2016; Hamdan et al., 2013).

A number of studies dealing with flipped classroom has been done previously. Afrilyasanti et al. (2016) conducted a research which concerned about the effect of the implementation of flipped classroom model toward students' writing ability and individual learning differences. The findings of the study found that there are significant differences on students' writing ability toward the implementation of flipped classroom. Students' with different learning styles achieved differently based on their learning styles. In addition, an action research study by Sun (2017) about the implementation of flipped classroom also talked about students' attitude. The study found out that there is positive result of implementing flipped classroom which foster students' critical thinking. However, the teacher finds a larger gap between high and low achievers. The low achievers' achievements are getting worse at the end of the semester. Ahmed (2016) conducted a research which examined both students' achievement on writing skill and students' attitude to flipped classroom. The study indicates that by the application of flipped classroom model, students' performance experiences improvement. In term of attitude, students perceive positively toward the learning model. 
Yang et al. (2019) conducted a research about the effect of implementing flipped classroom on high and low achievers' English Vocabulary Learning. The finding of the study showed that the implementation of flipped classroom gives benefits to high and low achievers' English vocabulary. Moreover, in term of students' attitude both the high and low achievers show positive attitude and even affect more for low achievers. From the above researches, the effect of implementing flipped classroom and students' attitudes toward flipped classroom are examined. There has not been any research which reveal what the teacher actually done in implementing flipped classroom model. There also a few researches which compare between the low and high achieving students' in term of their attitudes.

Therefore, this study is aimed to observe how teacher implement flipped classroom model in teaching English; students' achievement in learning English toward the implementation of flipped classroom; and opinion among low and high achieving students toward flipped classroom model.

\section{Methods}

In this research embedded mixed method research design was applied where both of quantitative and qualitative design were implemented. However, this research was done more in qualitative. The quantitative design was used to support the data resulted by the qualitative design. To reveal the effect of flipped classroom toward students' English learning, quantitative design was applied. Meanwhile, to figure out the implementation and students' perception, qualitative design was applied. In order to get the data, there were two research subjects which were examined in this research. The teacher which was observed was the seventh-grade English teacher who teaches English using Flipped Classroom Model. The seventhgrade students of SMP Sapta Andika Denpasar were the subject of the study. The D class was chosen as the sample. The selection of this study sample was not individual randomization but only class randomization. Classes were chosen as they had been formed by the school and in accordance with school policy, the possibility effects of the condition of the students of knowing that they were involved in the experiment could be reduced, thus, this study really illustrated the effect of the treatment given. In order to collect the data for the study, there were four instruments required including the researcher as the main instrument; post-test; interview guide; and questionnaires. Post-test was given to the students to find out their achievement toward Flipped Classroom. The questionnaire was also employed to investigate students' opinion to the learning process. Meanwhile, in order to figure out how the teacher implement Flipped Classroom, interview was done and followed by employing questionnaire. To support the data about the implementation of Flipped Classroom, the lesson plans of the second semester were analyzed.

Before collecting the data, preliminary research was done first. Preliminary research was done in order to gain specific information about the teacher who was actually teaching English using Flipped Classroom, the school, the classroom situation and whether the school was appropriate to be researched. After preliminary research was done, an interview to the English teacher was conducted. It was then continued by giving the teacher questionnaire to be filled. To support the data obtained from the English teacher, the second semester lesson plan was analyzed. After the data were obtained from the teacher, the students were given a post-test. The post-test was given in order to measure the students' achievement toward the implementation of Flipped Classroom. As the measurement was done, questionnaire was given to the students. The questionnaire was employed to investigate the opinion of the students then compare the opinion between the high and low achieving students. The data obtained from the post-test was analyzed descriptively using descriptive statistics in which the mean, median, modus, the highest score, the lowest score and the standard deviation. Then the scores were analyzed using norm-referenced measure of five standard values which shows excellent, good, sufficient, insufficient and poor.

Table 1. Norm-referenced of five standard classification

\begin{tabular}{ll}
\hline Range score & Classification \\
\hline $\mathrm{Mi}+1,5 \mathrm{SDi} \leq \mathrm{Mi}+3,0 \mathrm{SDi}$ & Excellent \\
$\mathrm{Mi}+0,5 \mathrm{SDi}<\mathrm{Mi}+1,5 \mathrm{SDi}$ & Good \\
$\mathrm{Mi}-0,5 \mathrm{SDi}<\mathrm{Mi}+0,5 \mathrm{SDi}$ & Sufficient \\
$\mathrm{Mi}-1,5 \mathrm{SDi}<\mathrm{Mi}-0,5 \mathrm{SDi}$ & Insufficient \\
$\mathrm{Mi}-3,0 \mathrm{SDi}<\mathrm{Mi}-1,5 \mathrm{SDi}$ & Poor \\
\hline
\end{tabular}

Meanwhile in observing students' opinion and teachers' teaching preparation, descriptive qualitative was applied. The information of how teacher implement flipped classroom model and students' opinion toward the implementation of Flipped Classroom which were obtained from interview, questionnaires and document analysis was analyzed in form of description using interactive model from 
Miles \& Huberman (1994). The analysis consists of data collection, data reduction, data display and conclusion drawing. Furthermore, to figure out the differences between high and low achieving students' opinion toward Flipped Classroom, paired sample t-test was done. Before the data were analyzed using paired sample t-test, a normality test was needed. Normality test was required to find out whether the students' questionnaires outcomes were distributed normally or not. After normality test was conducted, the paired sample t-test could be done. The data which were calculated using SPSS 16 were presented in term of table. The $t$-table function was to figure out if there was a significant difference between the mean score of high achieving and low achieving students' questionnaire results. The t-obtained value was consulted with the value of t-table at the degree of freedom (df) $\mathrm{N}-1$. In this study, triangulation by data type and method was done. In this research, there was not only one instrument as the method in obtaining the data. This research employed post-test, questionnaire, and interview guide. The combination of quantitative data which were gained from test and qualitative data which were obtained from interview document analysis and questionnaire were considered as triangulation by data type.

\section{Result and Discussion}

\section{The implementation of Flipped Classroom for teaching English}

Before teaching, a lesson plan of the day should have been made. From the interview, it was found that the teacher made her own lesson plan and it was not downloaded from any sources. It could be seen from the statement stated by the teacher from the interview:

"I own two types of lesson plan which for a year that is the basic lesson plan used for all of English teacher at school. And another one my flipped classroom lesson plan which I prepare at the beginning of each chapter."

After the lesson plan was made, the teacher made the video. Before deciding to make the video, the teacher claimed that sorting the material was a must do thing. The material sorted had to match the learning chapter. The teacher also collected the material from several sources. Since the material was collected appropriately, the teacher chose and arranged the explanation which were going to be recorded in the form of video. The words chosen must be clear and easy to be understood by the students therefore, arranging words to be delivered was crucial. The teacher was also asked about whether she had used other sources as the learning materials. From the interview the teacher stated:

"Most of them are my own videos. Sometimes if I have no idea for making video, I download it from YouTube. When I have downloaded it from YouTube, I Combine it and relate it with the learning material."

In implementing Flipped Classroom there were several steps which were done by the teacher namely, pre-class, in-class, and post-class. In pre-class activity, the students watched the video and prepared themselves for the in-class activity.

Pre-class activity

Before entering the class, students were given the video. The students were given some times to watch the video then they were sent the quiz which related to the video. The students were allowed to do discussion with their friends in the discussion forum during they learned the video given. It could be seen from the teacher's statement:

"At home they watch the video, do the quiz or if I give them a file, the read it. Yes, they did the online discussion."

However, they should do the quiz by themselves. Besides doing the quiz, the students were also told to note the important things they found during watching the video. These should be done by the students in each online home learning to deepen their knowledge about the material learned.

In-class activity

The steps of teaching which was done by the teacher during in-class activity was divided into three, pre-activity, whilst-activity and post-activity.

Pre-activity

In pre-activity, the lesson was started by praying and greetings. The teacher also invited the students to do brainstorming to refresh their mind. The teacher also discussed the students' learning difficulties at home and provided feedback for the quiz which has been given during the pre-class activity which was done at home. In this activity the students were expected to participate actively and respond to the teacher. It could be seen that at the beginning at the lesson, the teacher checked the students' attendances and greeted them. The teacher also gave feedback to students' quiz. Thus, it could be 
concluded that during the pre-class activity the teacher greeted the students', checked students' attendances and prayed as the beginning of the lesson. The teacher also gave feedback to the students' quiz, reminded about the learning objective and asked about students' difficulties in learning at home. However, there were several differences found among the questionnaire and the lesson plan that in the questionnaire the teacher stated that in the pre-activity, the teacher reminded the learning objective and asked students' learning difficulties but these activities were not mentioned in the lesson plan. Whilstactivity. From the interview conducted when the teacher was asked about what they did in the classroom after learning at home and whether she encouraged the students in sharing thoughts, the teacher said:

"We do discussion and exercises. Yes, I do. There are usually some questions from my students."

During the whilst-activity, the learning was done by doing discussion and assignments. The discussion covered the difficulties which were found during learning through the video at home. Based on the interview, there were several activities done by the teacher and the teacher said:

"The activities are mostly about discussing students' problem and doing assignments. They sometimes read the difficult things they find when they noted it previously. Yes, because we have much time to discuss the students' problem, I think give satisfying solution for the students."

Students were invited to share every problem the faced. Students were also allowed to ask questions to the teacher. They were also allowed to share their thoughts with their friends. The students were given sufficient time to do the discussion. Moreover, the teacher claimed that she had given satisfying solution to each students' problem. When the students found any obstacles in doing the assignment, the teacher was ready to help them. The teacher stated that she could assist all of the students' problem during the class because she allocated more time in doing assignment.

Based on the data obtained by interview, questionnaire and lesson plan analysis, the activities which were done in whilst-activity covered discussion and assignment. During the discussion students shared their learning difficulties based on the material learned at home. Furthermore, when the students did the assignment, they were told to work in group. The teacher during this activity assisted the students' based on their needs in doing the assignment.

Post-activity

In ending up the lesson, the teacher stated that she always sums up the learning material on that day. It was done to help the students remember the learning material even the learning process had been done. In the post-activity which was shown in the lesson plan, the teacher did the learning reflection. It covered the conclusion of learning. The teacher also directed the students to next learning material which aligned with the statement filled by the teacher in the questionnaire.

\section{Post-class activity}

In post-class activity, the assessment was done. Post-class activity covered the assessment and the application of the material learned. Meaning that in this learning step, the students applied the learning material through projects and the teacher assessed students' projects. When the teacher was asked about the assessment given, the teacher said:

"I gave some quiz for them. Test is also given. Project and assignment also given to assess students' achievement."

In term of assessment, the teacher claimed that she always gives the quiz for the students. The quiz which was given was around five to ten questions. The quiz was a kind of pre-assessment which was given to the students before the in-class learning conducted. Meanwhile, after the learning in the classroom was conducted, the teacher gave them final project at the end of every lesson.

Through the teaching process using Flipped Classroom model, there were some obstacles found by the teacher. The problem first come from the creation of the video. It was delivered by the teacher from the interview. The teacher said:

"In term of providing video, I need to rethink about how the video should be delivered and find the easiest way the students can understand my video. No, they are not. But sometimes, the students just have problem in cellular data. Watching video needs cellular data, but I told them that this method is good for students because they can replay the video if they missed some explanations and making the video fits the students' economics."

Although in term of providing video, the teacher found difficulties, the parents did not complain about this method. Moreover, the cellular data was also become the problem. It was happened because not 
all of the students came from a rich family background. The students did not have sufficient cellular data to do the online learning. Thus, several students tended to be slow in responding the command given in the learning forum. The students also became slow in receiving the material and answering the quiz. This problem was also happened because there were not a lot of place with free Wi-Fi near their house. In term of the learning model, Flipped Classroom was considered to be a new learning model introduced to the students. Since they were taught English in the Elementary school, they were not familiar with learning using technology; therefore, at the first time the model was introduced they seemed to be very confused. Surprisingly, there were some students who ignored to watch the video because they thought that they would be explained about the material again at school. This problem sometimes forced the teacher to explained about the material briefly. In order to overcome the problem about the ignoration of the students, the teacher tried to remind them and told them that Flipped Classroom helped them in learning and it had many benefits for their learning.

The findings obtained resulted from the present research aligned with the previous research conducted by Afrilyasanti et al. (2016) which stated that in using Flipped Classroom as a learning model, the teacher should be well-prepared. In the present research, before the students could learn using Flipped Classroom, the teacher had to prepare several things included materials suited the learning objective, the video and the scripts for the teacher for creating the video which meant that the teacher had to be prepared.

it was discovered that the teacher prepared the video and quiz before the in-class meeting. The video which was given to the students was mostly recorded by the teacher herself. Since making the video needed extra consideration, the teacher focused on the right materials related to the objectives and the choices of words delivered to the students thus the video given was easy to be understood. This result aligned with the study from Herreid \& Schiller (2013) which claimed that a great video was difficult to be found.

Concerning with the teaching procedures, the teacher had accomplished the three steps of Flipped Classroom implementation including pre-class, in-class and post class activity. The implementation of Flipped Classroom which was done by the teacher has aligned with the syntax of Flipped Classroom from Estes et al. (2014) which claimed that in conducting the teaching and learning using Flipped Classroom there were three steps should be done namely, pre-class, in-class and post-class.

In term of procedure, the steps which implemented by the teacher had suited the syntax of Flipped Classroom implementation. In the pre-class the teacher did modelling by giving explanation through video and pre-assessment through quiz. During in-class activity the teacher did clarifying concepts and solving problem by doing discussion then gave the students the opportunity to try out their knowledge by doing assignments. In the post-class activity, the teacher had done assessment and application by giving students projects then assess them.

However, in implementing Flipped Classroom for teaching English, there were several problems found by the teacher. The problem mainly appeared because of the students' economics background. The students who did not have their owned phone had to share phone with their parents and this situation obstructed the learning process. The lack of cellular data owned by the students also became the problem. These problems were similar with the researches which found that the students could not connect to the internet because the students could not afford to buy cellular data (Soliman, 2016; Sun, 2017).

Several students also did not watch the given at school because the students thought that the material would be explained in the classroom meeting. A research from Soliman (2016) claimed that it is not guaranteed that Flipped Classroom makes all students watch the video at home

\section{Students' achievement toward Flipped Classroom}

The data obtained from the post-test were then analyzed using descriptive statistics to find out the mean, modus, median, standard deviation, the highest score and the lowest score. The analyzed results were presented in Table 2.

Table 2. The Descriptive Analysis of Post-test Result

\begin{tabular}{lc}
\hline & Analysis \\
\hline Mean & 73.9 \\
Median & 72 \\
Modus & 72 \\
Highest score & 100 \\
Lowest score & 52 \\
Standard Deviation & 8.6 \\
\hline
\end{tabular}


After the descriptive analysis was displayed, converting students' scores was required. This step was done to figure out the classification of students' score whether the score was considered to be excellent, good, sufficient, insufficient, and poor. It was also used to determine in which classification was the mean score obtained. The classification was presented in Table 3.

Table 3. Norm-referenced of five standard classification result

\begin{tabular}{llll}
\hline Range score & Interval & Frequency & Classification \\
\hline $\mathrm{Mi}+1,5 \mathrm{SDi} \leq \mathrm{Mi}+3,0 \mathrm{SDi}$ & $75 \leq 100$ & 17 & Excellent \\
$\mathrm{Mi}+0,5 \mathrm{SDi}<\mathrm{Mi}+1,5 \mathrm{SDi}$ & $58,3<75$ & 23 & Good \\
$\mathrm{Mi}-0,5 \mathrm{SDi}<\mathrm{Mi}+0,5 \mathrm{SDi}$ & $41,7<58,3$ & 1 & Sufficient \\
$\mathrm{Mi}-1,5 \mathrm{SDi}<\mathrm{Mi}-0,5 \mathrm{SDi}$ & $25<41,7$ & 0 & Insufficient \\
$\mathrm{Mi}-3,0 \mathrm{SDi}<\mathrm{Mi}-1,5 \mathrm{SDi}$ & $0<25$ & 0 & Poor \\
\hline
\end{tabular}

The post-test was taken by 41 students. The scores gained from the post-test were varied. Those variations of score then analyzed in Table 1 . From the analysis, it could be seen that the average score from the post-test was 73.9 with the high score was 100 and the lowest score was 52 . It was also seen that the median score was 72 and the modus was 72 which frequently appeared as the score. The highest score was achieved by only one student and the lowest score was also achieved by the one student. The seventh' grade minimum standard score in SMP Sapta Andika was 71 which means that they should get 71 or above to accomplish the learning. According to the post-test result, there had been $68.3 \%$ students accomplish the learning based on the minimum standard score. It meant that the majority of the students could answer the test properly. The mean score of the data was 73.9 which determined in the good classification as seen in Table 3. It was also supported by the frequency of the students' achievement was in the good classification.

Based on the resulted score obtained by employing post-test which was analyzed descriptively using descriptive statistics, it was obtained that the mean score was 73.9. The mean score obtained then converted into norm-referenced classification to figure out where the mean score was specified. Since the mean score obtained from the post-test was 73.9 in which the score is between $58.3<75$, the mean score classification was considered to be good.

In accordance with the previous research which was conducted by Ahmed (2016) and Alsowat (2016) about the effect of Flipped Classroom toward students' achievement which resulted that Flipped Classroom improves students' achievement, the present research also found that the students' achievement toward the implementation of Flipped Classroom was considered to be good. Aligned with the present result, Flipped Classroom affected students learning achievement compared to traditional classroom (Afrilyasanti et al., 2019).

\section{Students' opinion toward Flipped Classroom}

The data about students' opinion about flipped classroom were obtained from the result of the questionnaire which was filled by the students. The questionnaire was a mixed of close-ended and openended questionnaire. There are thirty statements which are used as the indicators to examine students' opinion toward Flipped Classroom model which was implemented by their English teacher in which the students should show their agreement by choosing one of the five responses namely, strongly agree, agree, uncertain, disagree and strongly disagree and one open-ended question in which the students should state their general opinion of the implementation of Flipped Classroom.

Based on the questionnaire employed, it was found that the average results of strongly agree response was $27.5 \%$, agree response was $59.60 \%$, doubtful response was $11.15 \%$, disagree response was $1.94 \%$ and strongly disagree response was $0.08 \%$. If it was calculated, the agree and strongly agree responses dominated students' opinion. The students mostly agreed that during the pre-class activity, the students enjoyed watching video, did they quiz and excited when the quiz was given. Through the in-class activity, the students were excited when they were allowed to do more discussion and share their thoughts about the video learned previously. The students were also glad in doing the assignment in the classroom since they were assisted by the teacher and it could solve their problem. In the post-class activity, the students were excited when they were given an interesting project at the end of the learning and they had to do it within groups or individually.

Therefore, it was concluded that during the implementation of Flipped Classroom for learning English, the students perceive the learning positively. This result was corroborated with the previous researches (Afrilyasanti et al., 2017; Ahmed, 2016; Norazmi et al., 2017; Sun, 2017) which claimed that 
Flipped Classroom could motivate and engage students in learning English. The implementation of Flipped Classroom could improve students' engagement during the teaching and learning processes which also foster students' critical thinking and learning interests (Ahmed, 2016; Soliman, 2016; Sun, 2017; Tran, 2017). Aligned with the previous research, the present research found that the students perceived the learning using Flipped Classroom positively. The students' mostly put positive responses on the questionnaire employed.

\section{High and low achieving students' opinion toward Flipped Classroom}

There were 41 students which were observed in this research. Based on Brown (2004) to figure out the high achieving students and high achieving students, the number of the students could not be divided into two. It should be divided into four, $25 \%$ of the top level, $25 \%$ of the second level, $25 \%$ of the third level and $25 \%$ of the fourth level which is seen to be the lowest. Therefore, the number of high and low achieving was obtained by choosing $25 \%$ students of the upper rank for the high achieving students and $25 \%$ students from the lower rank for the low achieving students. Thus, it was found that there were 11 students from the upper rank as the high achieving students and 11 students from the lower rank as the low achieving students. To find out whether there was significant different between high achieving and low achieving students' opinion, the data resulted from the questionnaire results were analyzed using paired sample t-test in SPSS 16. Before analyzing the data using paired sample t-test, normality test was done. The Table 4 showed the result of normality test which was done using SPSS 16.

Table 4. Test of Normality

\begin{tabular}{|c|c|c|c|c|c|c|}
\hline & \multicolumn{3}{|c|}{ Kolmogorov-Smirnov } & \multicolumn{3}{|c|}{ Shapiro-Wilk } \\
\hline & Statistic & df & Sig. & Statistic & df & Sig. \\
\hline high achieving & .278 & 11 & .017 & .808 & 11 & .012 \\
\hline low achieving & .208 & 11 & $.200^{*}$ & .923 & 11 & .340 \\
\hline
\end{tabular}

a. Lilliefors Significance Correction

*. This is a lower bound of the true significance.

The data were focused on the Shapiro-Wilk. The Shapiro-Wilk was used since the amount of the samples were under 50. It showed that the significant value of high achieving was 0.120 (sig. $>0.05$ ) and the low achieving was 0.340 (sig. > 0.05) which meant that the students' questionnaire results toward the implementation of flipped classroom was normally distributed. The next step conducted after the data was proven to be normally distributed was conducting Paired Sample T-Test. The Table 5 showed the result of calculating the main scores of high and low achieving students' opinions.

Table 5. Paired Samples T-test Result

\begin{tabular}{|c|c|c|c|c|c|c|}
\hline & \multicolumn{4}{|c|}{ Paired Differences } & \multirow{3}{*}{\multicolumn{2}{|c|}{$\begin{array}{r}\text { Sig. (2- } \\
\text { df tailed) }\end{array}$}} \\
\hline & \multirow{2}{*}{$\begin{array}{l}\text { Std. } \\
\text { Mean Deviation }\end{array}$} & \multirow{2}{*}{$\begin{array}{l}\text { Std. Error } \\
\text { Mean }\end{array}$} & \multicolumn{2}{|c|}{$\begin{array}{l}95 \% \text { Confidence Interval } \\
\text { of the Difference }\end{array}$} & & \\
\hline & & & Lower & Upper & & \\
\hline $\begin{array}{ll}\text { Pair } & \text { high achieving - } \\
1 & \text { low achieving }\end{array}$ & 5.0009 .747 & 2.939 & -1.548 & 11.548 & 1.7 & 110.120 \\
\hline
\end{tabular}

Based on Table 5, it was found that the significant different between high and low achieving students was 0.120 which was above 0.05 . The result showed that there was no significant different between high and low achieving students' opinion toward Flipped Classroom. It could be concluded that the high and low achieving students' opinions which were found through questionnaire resulting that there were no significant differences between high and low achieving students during the implementation of Flipped Classroom.

There were six disagree responses seen in the low achieving students' responses and there were only two disagree responses in the high achieving students' responses. The disagree responses from the low achieving students were from several statement such as: understanding the learning objectives; the classroom situation make the students to be not hesitate to share the problem; the students were given interesting project at the end of the learning; the video duration was not too long so it did not make the students feel bored; the students preferred doing discussion in the classroom rather than listening to the 
teacher explanation; and the students enjoyed when the material given was interesting. However, the disagree responses which came from the high achieving students were about the teacher did not need to improve anything about the video and the students were motivated to learn independently. The low achieving students stated more disagree responses which meant that the low achieving student had not comfortable yet with the implementation of Flipped Classroom. On the other side, the high achieving students only stated two disagree responses which meant that they had learned better by the implementation of Flipped Classroom. Therefore, there are differences in term of opinion among the high achieving students and the low achieving students. According to the obtained result from paired sample $t$ test, it was found that the significant value was 0.120 which was above 0.05 . resulting that there was no significant different found in term of opinion among the high and low achieving students. Both of the high achieving and low achieving students perceived the learning positively (Yang et al., 2016). The finding opposed the previous research (Nouri, 2016) which found that there was significant different between the high achieving and low achieving students' opinions showing that low achieving students tend to have more positive opinion. Even though the high achieving and low achieving students in this study stated differences opinion resulting from the questionnaire, the differences were not significant.

\section{Conclusion}

There are several things prepared by the teacher during teaching using Flipped Classroom; lesson plan and video. The video which is given to the students are mostly made by the teacher, therefore, picking the right material, easy and clear words must be chosen in order to make the students understand it easily. During the implementation of Flipped Classroom, the teacher always provided quiz for the students and asks the students to note the important things during the video. For in-class activity, the teacher allocates more time for discussion and assignment. For post-class activity, the teacher gives the students project which should be done in group or sometimes individually. Finally, during the implementation of Flipped Classroom there are several obstacles found including; students who share their phone with parents thus to watch the learning video, they have to wait their parents from working; lack of cellular data owned by the students.

\section{References}

Abdullah, N. S., Sumarwati, S., Aziz, M. I. A., Ziden, A. A., Razak, N. A., \& Jalil, S. A. (2020). Life and career skills amongst technical and vocational education and training (TVET) students. International Journal of Innovation, Creativity and Change, 11(12), 637-654. https://publisher.uthm.edu.my/ojs/index.php/oj-tp/article/view/6695.

Afrilyasanti, R., Cahyono, B. Y., \& Astuti, U. P. (2016). Effect of flipped classroom model on Indonesian EFL students' writing ability across and individual differences in learning. International Journal of English Language and Linguistics Research, 4(5), 65-81.

Afrilyasanti, R.,Cahyono, B. Y. \& Astuti, U. P. (2017). Indonesian EFL students' perceptions on the implementation of flipped classroom model. Journal of Language Teaching and Research. 8(3): 476-484. http://dx.doi.org/10.17507/jltr.0803.05.

Ahmed, M. A. E. A. S. (2016). The effect of a flipping classroom on writing skill in English as a foreign language and students' attitude towards flipping. US-China Foreign Language, 14(2), 98-114. https://www.academia.edu/download/43033422/2016.2_US-

China_Foreign_Language.pdf\#page $=25$.

Alsowat, H. (2016). An EFL flipped classroom teaching model: effects on English language higher-order thinking skills, student engagement and satisfaction. Journal of Education and Practice. 7(9). https://eric.ed.gov/?id=EJ1095734.

Amat, J. V., Lilik, H., \& Nuryadin, E. . (2014). An evaluation of the implementation of Curriculum 2013 at the building construction department of vocational high schoos in Yogyakarta. Journal of Education, 7(1). https://journal.uny.ac.id/index.php/joe/article/view/5757.

Basal, A. (2015). The implementation of a flipped classroom in foreign language teaching. Turkish Online Journal of Distance Education, 16(4), 28-37. https://doi. org/10.17718/tojde.72185.

Bergmann, J., \& Sams, A. (2012). Flip your classroom: Reach every student in every class every day. International society for technology in education. 
Bjork, C. (2005). Indonesian education: Teachers, schools, and central bureaucracy. Routledge.

Borrowski, T. (2019). The Battelle for Kids P21 Framework for 21 ${ }^{\text {st }}$ Century Learning. University of Illinois at Chicago.

Brown, H.D. (2004). Language Assessment Principles and Classroom Practices. San Francisco: Longman.

Chu, S. K. W., Reynolds, R. B., Tavares, N. J., Notari, M., \& Lee, C. W. Y. (2016). 21st century skills development through inquiry-based learning: From theory to practice. 21st Century Skills Development Through Inquiry-Based Learning: From Theory to Practice, August 2018, 1-204. https://doi.org/10.1007/978-981-10-2481-8.

Estes, M. D., Ingram, R., \& Liu, J. C. (2014). A review of flipped classroom research, practice, and technologies. International HETL Review, 4(7), 1-8.

Evseeva, A. \& Solozhenko, A. (2015). Use of flipped classroom technology in language learning. ProcediaSocial and Behavioural Sciences. 205-209. https://doi.org/10.1016/j.sbspro.2015.10.006.

Filiz, S., \& Benzet, A. (2018). A content analysis of the studies on the use of flipped classroom in foreign language education. World Journal of Education. 8(4). https://doi.org/10.5430/wje.v8n4p72.

Hall, A. H., \& DuFrene, D. D. (2016) Best Practices for Launching a Flipped Classroom. Business \& Professional Communication Quarterly, 234-242. https://doi.org/10.1177\%2F2329490615606733.

Hamdan, N., McKnight, P., McKnight, K. \& Arfstrom, K. M. (2013) A review of Flipped Learning. Flipped learning network.

Herreid, C. F., \& Schiller, N. A. (2013). Case studies and the flipped classroom. Journal of College Science Teaching, 42(5), 62-66. https://www.jstor.org/stable/43631584?seq=1.

Koyan, I. W. (2012). Statistik Pendidikan Teknik Analisis Data Kuantitatif. Universitas Pendidikan Ganesha Press.

Lou, Y., \& Li, Z. (2018). Effects of form-focused instruction in the flipped classroom model on non-englishmajored graduates' English writing. Asian Education Studies. 3(2). doi: https://doi.org/10.20849/aes.v3i2.373.

Marlina, M. E. (2014). Kurikulum 2013 yang Berkarakter. Jupiis: Jurnal Pendidikan Ilmu-Ilmu Sosial, 5(2). https://doi.org/10.24114/jupiis.v5i2.1112.

Miles, M. B., \& Huberman, A. M. (1994). Qualitative Data Analysis: An Expanded Sourcebook. Thousand Oaks, Sage Publications.

Norazmi, D., Dwee, C. Y., Suzilla, J., \& Nurzarina, A. S. (2017). Exploring student engagement in writing using the flipped classroom approach. Pertanika Journal of Social Science and Humanities, 25(2), 663-674. https://core.ac.uk/download/pdf/153832341.pdf\#page=177.

Nouri, J. (2016). The flipped classroom: for active, effective and increased learning - especially for low achievers. International Journal of Educational Technology in Higher Education, 13(1). https://doi.org/10.1186/s41239-016-0032-z.

Partnership for 21st Century Skills (2016). Framework for 21st Century Learning 01/16. http://www.p21.org/storage/documents/docs/P21_framework_0816.pdf.

Pearson. (2013). Empowering 21st century learners with results that matter. Pearson Education, Inc.

Retnawati, H., Hadi, S., \& Nugraha, A. C. (2016). Vocational High School Teachers' Difficulties in Implementing the Assessment in Curriculum 2013 in Yogyakarta Province of Indonesia. International Journal of Instruction, 9(1), 33-48. https://eric.ed.gov/?id=EJ1086958.

Saglam, D., \& Arslan, A. (2018). The effect of flipped classroom on the academic achievement and attitude of higher education students. World Journal of Education. 8(4). Doi: https://doi.org/10.5430/wje.v8n4p170.

Santosa, M. H. (2017). Learning approaches of Indonesian EFL Gen Z students in a Flipped Learning $\begin{array}{llllll}\text { context. Journal on English as a Foreign Language, 7(2), } 183 . & .\end{array}$ https://doi.org/10.23971/jefl.v7i2.689. 
Shafa, S. (2014). Karakteristik Proses Pembelajaran Kurikulum 2013. Dinamika Ilmu: Jurnal Pendidikan, 14(1), 81-96. https://doi.org/10.21093/di.v14i1.9.

Soliman, N. A. (2016). Teaching English for academic purposes via the flipped learning approach. $\begin{array}{llll}\text { Procedia-Social and } \quad \text { Behavioral } & \text { Sciences, }\end{array}$ https://doi.org/10.1016/j.sbspro.2016.10.036.

Sun, X. L. (2017, September). An action research study from implementing flipped classroom model in professional English teaching and learning. In 3rd Annual International Conference on Social Science and Contemporary Humanity Development (SSCHD 2017). Atlantis Press. https://dx.doi.org/10.2991/sschd-17.2017.63.

Tran, T. T. Q. (2017). Students' Perceptions of Flipped Model on Facebook for Educational Purposes. IOSR Journal of Research \& Method in Education, 7(3), 7-14. https://doi.org/10.9790/73880703020714 .

Trilling, B., \& Fadel, C. (2013). 21st Century Skills: Learning for Life in Our Times. Jossey-Bass.

Trucano, M. (2005). Knowledge Maps: ICT in Education. Washington, InfoDev/World Bank.

Uzunboylu, H., \& Karagozlu, D. (2015). Flipped classroom: A review of recent literature. World Journal on Educational Technology. 7(2), 142-147. http://dx.doi.org/10.18844/wjet.v7i2.46.

West, M., \& Vosloo, S. (2013). Policy Guidelines for Mobile Learning. UNESCO. http://unesdoc.unesco.org/images/0021/002196/219641E.pdf.

Shih-Ching, Y., Liu, Y. T., \& Todd, A. G. (2019). Effects of Flipped Classroom on High-and Low-achievers' English Vocabulary Learning. Journal of Asia TEFL, 16(4), https://10.18823/asiatefl.2019.16.4.12.1251. 